\title{
Primary school teachers' interviews regarding Pedagogical Content Knowledge (PCK) and General Pedagogical Knowledge (GPK)
}

\author{
Pavinee Sothayapetch $^{1^{*}}$, Jari Lavonen ${ }^{1}$ and Kalle Juuti ${ }^{1}$ \\ ${ }^{1}$ Department of Teacher Education, University of Helsinki, Helsinki, Finland \\ For correspondence: pavineenui@gmail.com
}

\begin{abstract}
Pedagogical Content Knowledge (PCK) and General Pedagogical Knowledge (GPK) are fundamental types of knowledge for a teacher that he or she must use in order to plan, teach in the classroom, and assess students' learning outcomes. This paper investigates experienced primary school teachers' PCK and GPK while teaching science in Finland and in Thailand. Teachers' interview data were analysed by using deductive and inductive content analysis. The analysis units were analysed according to the categories and sub-categories of PCK and GPK. In addition, the frequencies of all PCK and GPK sub-categories were counted and presented by country. The analysis revealed that the Finnish teachers had flexibility in their teaching: they did not have specific techniques with which to handle students; the techniques used depend on the situations occurring at the moment. There were no strict rules for student discipline in the class. They emphasised the teaching of concepts through textbook and computer materials. In Thailand, the teachers emphasised the teaching and learning of procedural knowledge and consequently used experimentation, along with authentic materials in the lab. There were student discipline problems in the classroom; therefore, rules were set up to cope with those problems.
\end{abstract}

Keywords: Primary school teacher, Pedagogical content knowledge, General pedagogical knowledge, Content analysis

\section{Introduction}

Science is one of the most difficult subjects for primary school teachers to teach (Musikul, 2007). Teachers feel that school science syllabi are full of scientific concepts, such as entities, models, phenomena, and processes. However, they attempt to teach and help the students to understand the concepts by explaining the meanings of the concepts, for example, through giving examples or applications in the domain of the concept. Elluch, Bellamine-Bensaoud, and Ben Ahmed (2006) state that teachers should be able to introduce scientific concepts through the use of science learning materials, performing science experiments or using various resources (movies, pictures, etc.). To attain learning goals in accordance with the national curriculum, teachers have an important role in scaffolding the students' learning processes. Brandsford, Brown and Cocking (2000) suggest that teachers are the key to enhancing learning at schools.

Teachers employ their knowledge base when they teach students in the classroom. Gess-Newsome and Lederman (1999b) argue that content knowledge, pedagogical knowledge, and pedagogical content knowledge form the primary knowledge base for teaching. In order to act as a professional teacher, a teacher should have different kinds of knowledge, not only subject matter or content knowledge but also knowledge of how to support students' learning. Teachers teach the students how to learn and help them to use the models of learning that will support the best academic, social, and personal growth. This is partly similar to what Williams (2003) states: for students will reach their potential, a teacher must pay more attention to the interplay between the science of teaching pedagogy - and the art of teaching.

Tobin et al. (1990) mention that teaching and learning in the elementary science classroom often focus on recitation and content coverage and that teachers often have limited pedagogical content knowledge (PCK), especially prospective and novice teachers. The teachers are afraid of unexpected problems when they teach science (Zemble-Saul, Krajcik, \& Blumenfeld, 2002). In addition, the report Science Education in Europe: Critical Reflections (2008) suggests that the limited range of pedagogy is one reason that students disengage from science. The main challenge for the teacher is to develop the students' understanding of this body of concepts. At the primary level, ways of constructing 
meanings for concepts that rely on a specialist vocabulary of words, symbols, mathematics, diagrams, and graphs are difficult for students.

This paper focuses on primary school teachers' knowledge: Pedagogical Content Knowledge (PCK) and General Pedagogical Knowledge (GPK). Van Driel et al. (1998) conclude, regarding the research on science teachers' PCK, that it appears that familiarity with a specific topic, in combination with teaching experience, positively contributes to PCK. Moreover, general pedagogical knowledge (GPK) may constitute a supporting framework for the development of PCK (pp.681). Consequently, preservice teachers and mentors working as experienced teachers are major groups in which to investigate PCK and GPK. Moreover, Nilsson and Loughran (2012) explore the development of primary science student teachers' PCK by focusing on experienced teachers because beginning teachers' PCK tends to have little meaningful personal conceptualisation. For this reason, their study makes a significant contribution to the field of PCK in pre-service teacher education because it explores how PCK can be used to shape learning about (science) teaching.

This paper aims to investigate the Pedagogical Content Knowledge (PCK) and General Pedagogical Knowledge (GPK) of Finnish and Thai primary school teachers in the context of teaching about an electric circuit and concepts related to the circuit. Therefore, the aspects of PCK and GPK are introduced. This introduction will be utilized in the development of an interview protocol for teachers.

\section{Pedagogical Content Knowledge (PCK)}

Many scholars have used PCK (Shulman, 1987) as a main organizing concept in research on teachers' knowledge. Chick, Baker, Pham, and Cheng (2006) emphasise student thinking, the understanding of procedural knowledge, knowledge of resources, aims for learning, classroom technique, purpose of content knowledge, and student understanding of conceptual knowledge as the essential elements of PCK. Pedagogical content knowledge (PCK) is a special knowledge domain that distinguishes teachers from other subject specialists (Shulman, 1987; Carlsen, 1999). As such, PCK has paved the way for understanding the complex relationship between the content of a subject and the teaching of a subject by using specific teaching and evaluation methods. PCK is a synthesis of all knowledge needed for teaching and learning a certain topic (e.g., Grossman, 1990; Nilsson, 2008). For example, Duschl, Schweingruber, and Shouse (2005) linked teachers' PCK to student learning in science, and therefore, PCK is an important part of the knowledge base of a teacher. Several scholars (e.g., Gess-Newsome, 1999a) include the following areas in PCK: teaching and collaboration strategies; knowledge about student interest, motivation, and learning of conceptual and procedural knowledge and skills; knowledge of student thinking, misconceptions, and the cognitive and affective demands of tasks and activities; knowledge about resources available to support teaching and learning; and curriculum knowledge and aims for student learning. For example, Hashweh (2005) has defined PCK as:

The set or repertoire of private and personal content-specific general event-based as well as story-based pedagogical constructions that the experienced teacher has developed as result of the repeated planning and teaching of, and reflection on the teaching of, the most regularly taught topics (p. 277).

In Europe, especially in Germany, France, and the Nordic countries, including Finland, instead of PCK, the term "didactics" or, more precisely, "didactical transformation" (in German, didaktische Transformation) has been used to describe processes similar to those described in discussion of PCK (Kansanen, 2002). For this research, the concept of PCK utilized by Chick, Baker, Pham and Cheng (2006) is selected. The PCK category emphasises student thinking, the understanding of procedural knowledge, knowledge of resources, aims for learning, classroom technique, the purpose of content knowledge and student understanding of conceptual knowledge. The definitions of all categories are presented in Table 1 below. 
Table 1 Definition of PCK category (Chick, Baker, Pham, \& Cheng, 2006)

\begin{tabular}{|c|c|}
\hline PCK Category: K & Definition: A teacher ... \\
\hline aims for lea & describes a goal for students' learning \\
\hline stud & $\begin{array}{l}\text { discusses or addresses students' ways of } \\
\text { thinking about a concept or recognizes typical } \\
\text { levels of understanding }\end{array}$ \\
\hline student's m & $\begin{array}{l}\text { discusses or addresses the way to prevent } \\
\text { student misconceptions about a concept }\end{array}$ \\
\hline procedural knowledge & $\begin{array}{l}\text { displays skills used for solving scientific } \\
\text { problems }\end{array}$ \\
\hline resol & $\begin{array}{l}\text { Discusses/uses the resources available to } \\
\text { support teaching }\end{array}$ \\
\hline class & or uses generic classroom pra \\
\hline purp & $\begin{array}{l}\text { sses reasons for content being included in } \\
\text { urriculum or how it might be used }\end{array}$ \\
\hline a of student 1 & es student's understanding of a scie \\
\hline represen & $\begin{array}{l}\text { discusses materials, pictures, or diagrams used } \\
\text { to introduce a scientific concept }\end{array}$ \\
\hline
\end{tabular}

General Pedagogical Knowledge (GPK)

GPK is a central component of teacher knowledge (König and Blömeke, 2011). According to Shulman (1987, p. 8), general pedagogical knowledge involves "broad principles and strategies of classroom management and organisation that appear to transcend subject matter", as well as knowledge about learners and learning, assessment, and educational contexts and purposes. Similarly, Grossman and Richert (1988) state that "GPK includes knowledge of theories of learning and general principles of instruction, an understanding of the various philosophies of education, general knowledge about learners, and knowledge of the principles and techniques of classroom management" (p. 54). The GPK concept of Morine-Deshimer and Kent's (1999) is used for this research. They divided GPK into three main categories as follows: instructional model (teaching method), classroom management, and classroom communication.

I. Classroom management is consistent in noting the general principles of teacher behaviour that promote student achievement. Classroom management focuses on three major components:

- Content management does not refer to skills peculiar to teaching a particular subject but rather to those skills that cut across subjects and activities (Froyen \& Iverson, 1999). Doyle stressed that the core of instructional management is gaining and maintaining student cooperation in learning activities (as cited in Froyen \& Iverson, 1999). Content management occurs when teachers manage space, materials, equipment, the movement of people, and lessons that are part of a curriculum or program of study.

- According to Iverson and Froyen (1999), conduct management refers to the set of procedural skills that teachers employ in their attempt to address and resolve discipline problems in the classroom. For example, when students are disobedient in the classroom, a teacher uses certain methods to reinforce the students by giving rewards, admiration, blame, etc. If a student has a severe problem, the teacher may contact the student's parents or guardians so as to cooperate in solving the problem.

- Covenant management stresses the classroom group as a social system that has its own features that teachers have to take into account when managing interpersonal relationships in the classroom.

The three aspects of classroom management, as mentioned above, are the main protocols for interviewing teachers.

II. Instructional methods and teaching methods or models are used as synonyms. Joyce and Weil (1996) have defined teaching models as follows:

"A teaching model is a pattern or plan that can be used to shape a curriculum or course, select instructional materials, and guide a teacher's actions. Models are designed to attain specific goals. When a teacher identifies a goal, he or she selects a particular strategy designed to attain that goal." 
According to Joyce and Weil (1996), the models of teaching have been grouped into four families that share orientations toward human beings and how they learn. These families emphasise different goals for teaching and learning and different types of social interaction. The families are the social family, the information-processing family, the personal family, and the behavioural systems family, along with the teaching method concept of Joyce, Calhoun, and Hopkins (2002). These families overlap, and a single teaching method could have characteristics of several families. This classification of teaching methods is not especially designed for science education. However, primary teachers are teaching all primary-level school subjects and adopting ideas from the teaching of other subjects for use in science teaching. Therefore, the classification offers a broad view of all possible teaching methods / models for use in science education.

- The teaching models that belong to the social family emphasise the learning of social skills while learning content knowledge. Classroom management plays a key role in organizing teaching and learning in the context of social family teaching models. Examples of such models include social inquiry, the laboratory method, role-playing, and group investigation.

- The information-processing family of teaching models emphasises enhancing human beings' innate drive to make sense of the world by acquiring and organising data, generating solutions, and developing concepts. Some models focus on providing the learner with the information, whereas some emphasise concept formation, and some generate creative thinking, such as scientific inquiry, concept attainment, inquiry training, etc.

- The personal family of teaching models focuses on the unique character of each person and his or her struggle to develop as an integrated, confident, and competent personality. Human beings are able to develop and achieve a sense of self-worth and personal harmony, e.g., nondirective teaching, self-actualisation, etc.

- The behavioural system family of teaching models emphasises modifying the behaviour of human beings in order to allow them respond to information about how successfully tasks are navigated, e.g., social learning, simulation, and direct teaching.

The overall pictures of the teaching model that are mentioned above make up the outline of this study in terms of how the teacher teaches the students in the classroom by analysing the classroom phenomenon, along with the concept of teaching models. When collecting data about teachers' teaching, this outline helps to easily categorise and group all data.

III. Classroom communication is the interactive language and responses that are exchanged between students and teacher. Hurt, Scott, and McCroskey (1978, pp.3) mention that "Communication is the crucial link between a knowledgeable teacher and a learning student." Teaching and learning cannot occur without communication. The concept of Anderson and Garrison (1998) was adapted in this paper. There are three common types of classroom interaction. The term of interaction emphasises interaction between teacher and students through using words, discussing, explaining, and asking during teaching time. Moreover, interaction also focuses on interaction between students through small group work activities, discussions in laboratory work, and group project presentations. Moreover, two forms of communication: verbal and non-verbal communication (Johnson, 1999) was applied to Anderson and Garrison's concept too. Three types of classroom communication as follows:

- Teacher-student interaction: a teacher and students respond to one another or interact together through verbal or non-verbal responses, such as questioning, discussing, presenting, explaining, answering, complimenting, touching, facial expression, and personal space during classroom teaching.

- Student-student interaction: students respond to one another or interact together through verbal and non-verbal responses, such as discussing, brainstorming, talking, writing, questioning, answering, touching, and facial expression during classroom learning.

- No interaction: a teacher and students do not respond to one another or interact at all in the classroom, such as each student doing on her/his own work during an exercise. 
These three types of classroom communication are the framework via which to handle research data easily when analysing it.

Figure 1 summarises the theoretical framework of this research project. This framework was used to plan the interview protocol and interpret the results.

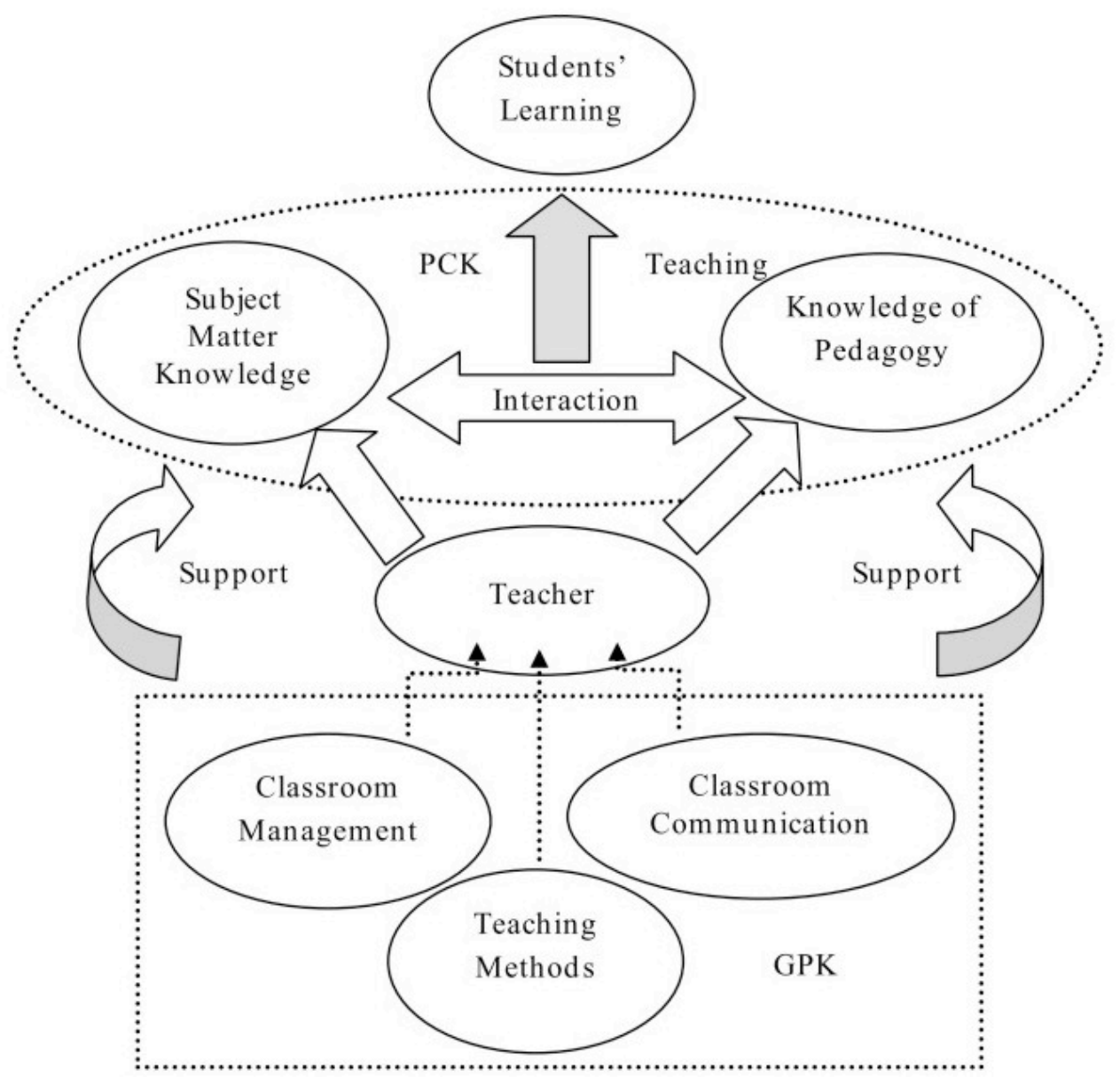

Figure 1. Theoretical framework summarizes teachers' knowledge base

Figure 1 also summarizes the main theoretical views in my doctoral dissertation. The harmony of two theories on teacher knowledge, PCK and GPK, shows the knowledge a teacher employs in classroom teaching. According to the diagram, a teacher blends content knowledge and knowledge of pedagogy when teaching in the classroom. Shulman's PCK concept is topic- or concept-specific, and it explains how particular topics are taught to learners with diverse interests and abilities. Therefore, two kinds of knowledge interact while a teacher is planning a lesson in order to support the students' learning. From the point of view of a teacher, the question is as follows: how does a teacher transform his or her personal understanding of content knowledge into forms that are understandable for students? This thinking is called "pedagogical reasoning." In classroom situations, the teacher is not always able to use only PCK, because (s)he has to handle unexpected problems; therefore, general pedagogical knowledge (GPK) supports the teacher in the classroom through, e.g., classroom communication and conduct management (under classroom management).

As mentioned above, the purpose of this research project is to investigate the PCK and GPK used by primary school teachers while teaching science in Finland and in Thailand. The research questions that guided this research are:

- How do primary school teachers express their viewpoints on PCK and GPK while they plan or implement the electric circuit lesson at the primary level in both countries?

- How do Finnish and Thai primary school teachers' expressions of PCK and GPK differ in the context of the electric circuit lesson? 


\section{Methods}

In order to answer the research question, semi-structured interviews were conducted in this paper. The interview protocol emphasised the concepts of PCK and GPK in the context of electric circuit teaching at the grade 6 level (see Appendix A).

\section{Participants}

There were six experienced primary school teachers, consisting of three Finnish primary school teachers in Helsinki and three Thai primary school teachers in Bangkok, who were interviewed for this study. The Finnish teachers were selected based on their schools' organising teaching practises: two from a university training school and one from a municipal school. Among Thai participants, one Thai teacher was from an "ordinary" comprehensive school, and the others were from a demonstration (teacher training) school. All Finnish and Thai teachers were experienced teachers and have been or were working as mentor teachers in teacher education. Consequently, teachers were not "ordinary" but had a strong background in education; it is plausible that they have reflected on teaching more than ordinary teachers have. A mentor teacher teaches student teachers, in addition to students in the classroom, or mentors them regarding their practice teaching. Therefore, the outcomes of this case study offer information about what might be the optimal situation for teaching and learning in Finnish and Thai classrooms and situations in which student teachers have their practice teaching. The selection of the teachers could be called purposeful, which means that the informants were chosen for specific purposes in order to obtain rich data. This type of sampling selects information-rich cases for in-depth study. As one type of purposive sampling, the point of criterion sampling is to understand cases or individuals who meet a certain criterion, thereby providing rich data (Patton, 2002). The criteria for the selection of teachers were:

1) the teacher has recently taught or was teaching the electric circuit lesson at the grade 6 level.

2) the teacher was currently or has been a mentor teacher who has supervised student teachers during practice teaching.

According to the interviews, personal information results of the interviewees showed that all Finnish primary school teachers had a master's degree in pedagogy. In Thailand, two teachers had master's degrees in different majors: Elementary Education and Curriculum and Educational Supervision. One Thai teacher had a doctoral degree in educational research. There was one Finnish teacher who had 28 years of teaching experience. Meanwhile, one Finnish teacher and two Thai teachers had 25 years of teaching experience, another Thai teacher had 19 years, and another Finnish teacher had 8 years. In addition to the teaching role, the primary school teachers from these two countries had other positions in the school; for example, one Finnish teacher had worked in an administration team, supervising student teachers at the same time. One Finnish teacher had participated in writing textbooks. In summary, all teachers were very experienced and educated. Therefore, this paper offers an optimal view of a primary teacher's PCK and GPK in the context of the electric circuit in Finland and in Thailand.

\section{Interviews}

Semi-structured interviews were conducted in Finland and in Thailand. There were several openended questions, which allowed the teachers tell about their use of PCK and GPK in the planning and implementation of science teaching in the context of the electric circuit. An interview in the English language was prepared for the Finnish teachers. The participants were interviewed, and the interviews were recorded with a tape recorder. The explanation of the interview procedure in both countries is described separately because of the different regulations regarding how teachers should be contacted in Finland and in Thailand. In Thailand, before performing the interviews, permission letters from the thesis supervisor were sent to the principals, and they were asked for their permission to interview the teachers. Then, the interview appointment was agreed to. In Finland, the teacher connection was made directly, and the interview appointment was agreed to. The teachers were invited via email, and three teachers responded voluntarily.

\section{Interview situations}

The average time for interviews was an hour per participant. All participants selected their classrooms as the place for the interviews. Firstly, the interviewer introduced herself and told them about her personal and educational background. Interview started by questions about the personal 
information in order to relax teachers. The interview situations had a normal and comfortable atmosphere. In the beginning of the interview, the Finnish teachers were little nervous about English use, but during the interview, they relaxed. The participants' gestures and manner were noticed and this information was used to ensure a good situation for both parties (interviewer and interviewees). Importantly, leading or suggestive questions were avoided. The teachers were let express their viewpoints freely based on the question aims and available time. To analyze the original expressions, the steps below were followed.

\section{Interview data analysis}

Firstly, all the teacher interviews were transcribed. The whole interview was considered as data for analysis. Therefore, the role of interview questions was to be supportive of teachers' thinking. During the interview, it happened that teachers were telling about a certain issue during several of the questions asked. The interviews were analysed using inductive and deductive content analysis (Elo \& Kyngäs, 2008).

First, the teachers' interviews were transcribed. The transliterated texts were read several times so as to ensure an accurate interpretation of the teachers' expressions. While reading them, notes and headings were written in the text in bold (see Appendices B and C). Then, the written text is read again to check as many headings and notes written down in the margins as are necessary to describe all aspects of PCK and GPK. Consequently, the lists of headings represented the analysis units (subcategories) used in the inductive approach. After the analysis units (sub-categories) were analyzed inductively, they were analyzed deductively based on the categories and sub-categories of PCK and GPK. Lastly, I counted how many times the teachers expressed ideas related to the sub-categories, and the numbers were presented by country (see Tables 3 and 4).

\section{Results}

This study presents the interviews of six teachers in the context of teaching the electric circuit at the grade 6 level in Finland and in Thailand. The aim of the interview was to compare the viewpoints on PCK and GPK that teachers employ in planning and teaching the electric circuit topic at the elementary level in both countries. The teacher interview protocol consists of three parts: personal information and teachers' electric circuit-related PCK and GPK.

\section{How do teachers employ PCK in their teaching?}

The results of analysed expressions from the point of view of PCK are presented in Table 3. The frequencies show how many times those three teachers in Finland and Thailand described issues related to PCK in each PCK category. Each sub-category is based on the interviews and was created during the content analysis. The frequencies were quite close to one another in most sub-categories in the two countries.

Table 3. Frequencies of each PCK sub-category in the interviews of the teachers in Finland and Thailand

\begin{tabular}{|c|c|c|c|}
\hline \multirow[t]{2}{*}{$\begin{array}{l}\text { PCK category: } \\
\text { knowledge of }\end{array}$} & \multirow[t]{2}{*}{$\begin{array}{l}\text { Sub-categories } \\
\text { (Analysis units) }\end{array}$} & \multicolumn{2}{|c|}{$\begin{array}{l}\text { Frequency } \\
\text { expressions }\end{array}$} \\
\hline & & Finland & Thailand \\
\hline \multirow{4}{*}{$\begin{array}{l}\text { Pedagogy } \\
\text { - aims for learning }\end{array}$} & & & \\
\hline & $\begin{array}{l}\text { Importance of electricity and its relationship to } \\
\text { everyday life }\end{array}$ & 1 & 3 \\
\hline & Understand how the electric circuit works & 2 & 1 \\
\hline & $\begin{array}{l}\text { Understand the important concepts related to } \\
\text { the electric circuit }\end{array}$ & 3 & 3 \\
\hline \multirow[t]{2}{*}{ - student thinking } & $\begin{array}{l}\text { Ask questions / discuss and engage in hands-on } \\
\text { activity in order to support thinking }\end{array}$ & 15 & 10 \\
\hline & $\begin{array}{l}\text { Use media (TV, Internet, movies) in order to } \\
\text { support student thinking }\end{array}$ & 3 & - \\
\hline \multirow[t]{2}{*}{ - misconceptions } & $\begin{array}{l}\text { Support students in learning concepts through } \\
\text { an activity }\end{array}$ & 9 & 6 \\
\hline & $\begin{array}{l}\text { Support students in learning concepts through } \\
\text { the use of textbook }\end{array}$ & 6 & - \\
\hline - procedural knowledge & Students perform an experiment with authentic & 9 & 11 \\
\hline
\end{tabular}




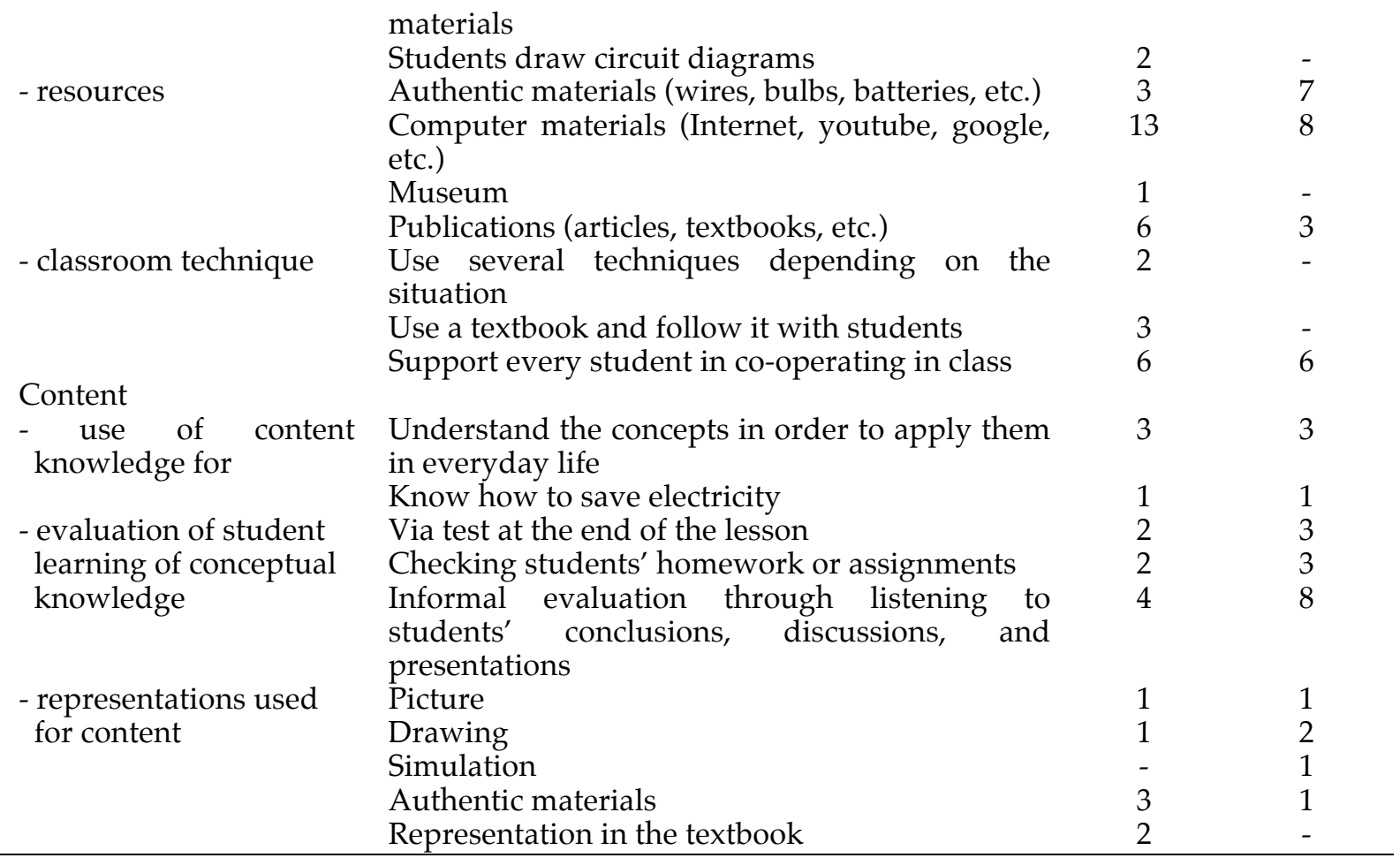

The teachers shared similar aims in terms of learning about the electric circuit and the concepts related to it, such as making simple couplings, concepts used for describing the electric circuit, saving of electricity, and the use of electricity in everyday life. Direct quotations from the teachers support these conclusions:

After they learned this lesson, they got some kinds of skill to learn to solve some kind of problem in their everyday lives, for example... well, whatever... the TV is not working also. If they would think that OK...there is no electricity. What should I do? How do I probably fix it? Can I fix it myself? Should I plug it? And so on. (FT1)

I usually do [demonstrations] because it is very important to motivate them or talk about [concepts related to the electric circuit]... we need the electricity. (FT2)

After they have learned, they will understand the reason why they have to learn about the electric circuit or electricity because it is close to our lives and we must know how to use it in a safe way. (TT2)

Scientific issues happen in everyday situations. I always take one of those situations relating to the lesson in my teaching. For example, the news talked about...eer... the solar cell. Then, I take this issue to the classroom for a discussion about how we save electricity. (TT3)

Moreover, all teachers enhanced the students' procedural knowledge through an experiment with authentic materials. Drawing a circuit diagram and symbols was used as one way to support the procedural knowledge of students in Finland.

Yes...we have learned about the circuit diagram drawing and then...errrrr...there are all kinds of markings, and then, they have been open and closed-circuit...then, they should do the connections like the picture is. (FT1)

The Finnish teachers stimulated student thinking by asking questions and using media. The frequencies in both of these sub-categories were higher than in Thailand. In contrast, the Thai teachers did not mention the use of media to stimulate student thinking at all.

Museums and publications, such as articles, books, etc., were mentioned as information sources by the Finnish teachers in order to broaden student knowledge beyond the textbook. One Finnish teacher used the museum as one source for enhancing students' learning. Finnish Teacher 2 expressed, "I took the class to the museum of technology in Helsinki, and they have a special area about electricity, so we had an 
overall guided tour, and then, there was a paper sheet thing, and I said that this is about the electricity. You go through the exhibition and fill out the paper." Moreover, computer materials were mostly referred in both countries as other resources. About the representations of concepts, the electric circuit concept was introduced via the Finnish textbook as well as authentic materials. In Thailand, the Thai teachers employed various ways of representing the concepts, i.e., pictures, simulations, authentic materials, and drawings.

Afterwards, I make a conclusion about what they have been doing, and then, after that, we might look at the textbook and give names to the concepts. You know, after work, we might look at the textbook and give them the concept. (FT3)

In the electric circuit lesson, I draw a picture by myself or sometimes use PowerPoint or a simulation to show students that if I cut this way from the picture, the light should be shut. (TT1)

If I need them to get the concept, I will use the complete picture, but I prefer the students to draw by themselves because they will practice their hand drawing at the same time. (TT2)

I review the knowledge of electrical symbols, such as bulbs, wires, and batteries, with students via PowerPoint or realistic figure. (TT3)

Regarding classroom technique, two Finnish teachers expressed that they used several techniques for instruction, depending on the situation in the classroom. For example, they made students ready and drew their attention through singing a song, telling a story, and so on. One Finnish teacher followed the textbook with the students, while no Thai teachers mentioned the use of the textbook at all. Furthermore, the teachers from both countries proved the students' understanding of the conceptual knowledge via the students' conclusions, discussions, and presentations in the classroom.

How do teachers employ GPK in their teaching?

Table 4 presents the frequencies showing how many times those three teachers in Finland and Thailand described issues related to GPK in each GPK category. Each sub-category is based on the interviews and was created during the content analysis.

Table 4. Frequencies of each GPK sub-category in the interviews with the teachers in Finland and Thailand

\begin{tabular}{|c|c|c|c|c|}
\hline \multicolumn{2}{|c|}{ GPK category } & \multirow[t]{2}{*}{$\begin{array}{l}\text { Sub-categories } \\
\text { (Analysis Units) }\end{array}$} & \multicolumn{2}{|c|}{$\begin{array}{l}\text { Frequency number of } \\
\text { expressions }\end{array}$} \\
\hline Main & Sub & & Finland & Thailand \\
\hline \multirow{19}{*}{$\begin{array}{l}\text { 1.Classroom } \\
\text { management }\end{array}$} & 1.1 Content mana & ement & & \\
\hline & - Curriculum & $\begin{array}{l}\text { Regard and follow the science } \\
\text { curriculum }\end{array}$ & 3 & 3 \\
\hline & - Teaching & Content knowledge & 5 & 4 \\
\hline & preparation & Plan for teaching & 5 & 6 \\
\hline & - Learning & Textbook & 6 & 3 \\
\hline & material & Blackboard & 1 & 3 \\
\hline & & Computer materials & 13 & 10 \\
\hline & & $\begin{array}{l}\text { Authentic materials, such as bulbs, } \\
\text { wires, batteries, etc. }\end{array}$ & 6 & 8 \\
\hline & & Pictures & 8 & 2 \\
\hline & & Visualizer & 3 & - \\
\hline & - Student & In small group & 11 & 13 \\
\hline & arrangement & In pairs & 6 & - \\
\hline & 1.2 Conduct mana & gement & & \\
\hline & - Resolve & Set the rules in the classroom & 2 & 4 \\
\hline & discipline & Use a reinforcement approach & - & 3 \\
\hline & problem & Few discipline problems found & 2 & - \\
\hline & $\begin{array}{l}1.3 \text { Covenant man } \\
\text { - Interpersonal } \\
\text { relationships }\end{array}$ & $\begin{array}{l}\text { Wement } \\
\text { group and discuss together in a small }\end{array}$ & 7 & 6 \\
\hline & $\begin{array}{l}\text { among } \\
\text { students }\end{array}$ & $\begin{array}{l}\text { Use nice words and be friendly with } \\
\text { others }\end{array}$ & 3 & 3 \\
\hline & $\begin{array}{l}\text { - Relationship } \\
\text { between }\end{array}$ & $\begin{array}{l}\text { Be nice, reasonable, and friendly with } \\
\text { students }\end{array}$ & 1 & 1 \\
\hline
\end{tabular}




\begin{tabular}{|c|c|c|c|c|}
\hline & $\begin{array}{l}\text { teacher and } \\
\text { students }\end{array}$ & $\begin{array}{l}\text { Help and encourage students when } \\
\text { they have any kinds of problem }\end{array}$ & 3 & 3 \\
\hline \multirow{4}{*}{$\begin{array}{l}\text { 2.Instructional } \\
\text { methods }\end{array}$} & The social & Laboratory method/practical work & 11 & 13 \\
\hline & $\begin{array}{l}\text { family model } \\
\text { - The } \\
\text { information } \\
\text { processing } \\
\text { family model }\end{array}$ & $\begin{array}{l}\text { and learning in a small group } \\
\text { Concept attainment and the use of a } \\
\text { variety of resources to support the } \\
\text { learning of concepts }\end{array}$ & 19 & 2 \\
\hline & $\begin{array}{l}\text { - The personal } \\
\text { family model }\end{array}$ & $\begin{array}{l}\text { Students must have scientific skills, } \\
\text { such as being open-minded, curious, } \\
\text { observant, wondering, able to think, } \\
\text { ask, and discuss, as well as having a } \\
\text { problem-solving attitude. }\end{array}$ & 5 & 6 \\
\hline & $\begin{array}{l}\text { The } \\
\text { behavioural } \\
\text { systems family } \\
\text { model }\end{array}$ & $\begin{array}{l}\text { Teaching with the "rules and } \\
\text { reinforcement" approach in order to } \\
\text { control the students' behaviour }\end{array}$ & 3 & 7 \\
\hline \multirow[t]{3}{*}{$\begin{array}{l}\text { 3.Classroom } \\
\text { communication }\end{array}$} & $\begin{array}{l}\text { Teacher- } \\
\text { student }\end{array}$ & $\begin{array}{l}\text { Read togethe, ask questions to the } \\
\text { whole class, have students answer, } \\
\text { engage in classroom discussion, have a } \\
\text { teacher or student present to whole } \\
\text { class, have a teacher touch or smile at } \\
\text { students }\end{array}$ & 8 & 10 \\
\hline & $\begin{array}{l}\text { Student- } \\
\text { student }\end{array}$ & $\begin{array}{l}\text { Discuss in a small group, engage in } \\
\text { practical work in a small group }\end{array}$ & 10 & 17 \\
\hline & - No interaction & $\begin{array}{l}\text { Students read the textbook and do } \\
\text { homework exercises/assignments on } \\
\text { their own }\end{array}$ & 2 & 3 \\
\hline
\end{tabular}

Table 4 presents the results for the analysed expressions from the point of view of GPK. It shows that overall, participants accepted the fact that curriculum is important in their profession; they regarded and followed the science curriculum when planning the lessons. "You have to... I think it [curriculum] controls our job and that we have to use it. I don't know, how do you say... kind of, well... it's kind of law. It has a static nature, being kind of... it's really... you have to follow it. You can't skip it." (FT2). Furthermore, all teachers recognized the content knowledge in their lesson plans in terms of surveying the overall contents of the lesson before beginning teaching that lesson and then considering the teaching method. The Finnish teachers expressed their ideas about learning materials: the textbook is always important in order to present the important concepts in the lesson, as well as computer materials (Youtube, webpages), authentic materials, and pictures, which were also employed in electric circuit teaching. For Thai teachers, the first three learning materials used in teaching were computer materials, authentic materials, and the blackboard.

In addition, a minor difference was that Thai teachers always arranged students in small group, while Finnish teachers organised students both in pairs and in small groups for electric circuit instruction.

Sometimes, they were sitting in pairs. Sometimes, they were sitting in small groups. (FT1)

They decided by themselves...I quite often say to make groups from 1 to 4 . In grade 6, I have 26 students, and if you try to have much hands-on teaching, it's almost impossible...or in pairs...I have 10 or 12, so they can work in pairs. (FT2)

I form students into groups of around 3-4 people in one group. The maximum is four. (FT3)

Referring to discipline problems in terms of the conduct management (sub-category of GPK), in Finland, there were fewer discipline problems during teaching.

No...no... Actually, I have taught many classes during the eight years. I have never met a class that would have discipline problems after teaching them unlike, so I think it relates to the interaction...between teacher and students, and the students want to act so that they please the teacher as they like the teacher and they respect the teacher. (FT1)

I really don't have any discipline problems because I believe that when I teach in the proper way...when my methods are suitable...eer...when my methods are such that will interest or will motivate them into doing the lesson, they quite seldom have any discipline problems. (FT3) 
In Thai classrooms, there were minor discipline problems, such as talking in a class, walking in a class, etc. Therefore, Thai teachers emphasised the rules used in the classroom to solve student discipline problems. When the problems occurred, most Thai teachers solved the problems by using the reinforcement approach. Thai Teacher 2, as an example, said, "Student discipline is about the positive and negative reinforcement, such as group scores, compliments, rewards, and giving stars." All participants supported the relationships among students by letting them working together in pairs or in groups and provided students with the opportunity to discuss and solve problems.

The second GPK category was teaching methods. The frequencies showed that the two most used teaching models/methods in Finland belong to the information processing family and the social family. According to the Finnish teachers, the textbook, computer materials, and publications used in teaching the electric circuit support the students' concept formation. Meanwhile, the Thai teachers used the teaching models/methods that belong to the behavioural system family in their teaching because of student discipline problems in the classroom. As Thai Teacher 1 said, "I set the rules in the classroom or in the lab and explain their responsibilities in terms of taking care together or keeping things orderly in the lab." However, laboratory method and experiments performed as group work in the social family were the main model/method for both countries for electric circuit instruction. Students had to discover and solve the problems (e.g., electric circuit connections) together in pairs, in small groups, or by themselves under the teacher's facilitation. In addition, both Finnish and Thai teachers emphasised the personal family of models in terms of students' use of scientific abilities and skills, such as questioning ability, observation, being curious, and using problem-solving skills.

Regarding the last category of GPK, classroom communication, the analysis of the interviews showed that all interviewed teachers had three types of communication approaches. Regarding teacherstudent and student-student interaction, this means that the teacher and students cooperated in working with the electric circuit by discussing, asking questions, answering questions, working with ideas to solve scientific problems, listening to the different viewpoints together, expressing themselves facially (smiling, nodding or shaking the head), and touching one another. One Finnish teacher proposed an interesting idea about non-verbal communication:

I think non-verbal communication is very important. Although I think we are not supposed to touch pupils, I do if I know that the pupil that I'm going to touch will not dislike it, so I can be very close or far away if I know that this pupil doesn't want to be so close, and so on, but I think non-verbal communication is more important than verbal. (FT1)

Teachers in Finland and in Thailand emphasised versatile forms of interaction within their classrooms. One important interaction style is when students interact with other students in pairs or in small groups while discussing, sharing ideas, presenting work, smiling, laughing, and touching.

Well, if I put them working in here, then I will choose their pairs so that I would think that it would be easy for them to discuss together, and also, if they are working in small group, it's important there is no one dominating the discussion so that the silent ones will open their mouths about what they are thinking. (FT1)

It always depends on the situation, but in a way, I'm a traditional teacher, and in the sixth grade, I also think it's important that they learn to like... read in a book, and we sometimes go through the text together and talk about it. (FT2)

I aim to be among the students as much as I can. I aim to walk around, help them and encourage them, and yes I also teach, but my moments of direct teaching are quite short. Mainly, I see my role as that I help them to study. I help them to set their own goals. And I help them to reach their own goals. (FT3)

Actually, students do not dare to come or talk to me, but I try to use conversation, not beating. I sometimes express to students that I care about them and worry about them all the time. (TT3)

No interaction aspect was present when students worked on their own. "You know, after the experiment, we might look at the textbook and give them the concepts. Then, they might do some exercises from the book," Finnish Teacher 3 expressed. Similarly, Thai teacher 3 said "Students will have their own lab book. I don't give them much homework. The lab book is sent at the end of lesson to ask what the concept of the day is. What concept does this lesson give you?" 


\section{Discussions}

The main result of this research project was that the experienced Finnish and Thai primary school teachers' expressions regarding PCK and GPK related to the 'electric circuit' could be considered rather similar. Five of six teachers had graduated from a Master's level program. These teachers were working also as mentor teachers in teacher education, and consequently the results are telling on practices in optimal situations.

A textbook was used to present the concepts to the students and to prevent student misconceptions. Moreover, the Finnish teachers employed computers as resources in order to obtain more information on the electric circuit topic. The social family of teaching models was a major model for teaching in both countries. Moreover, Finnish teachers emphasised teaching models that belonged to the information-processing family. Teachers emphasised teacher-student and student-student interaction in their instruction. However, the Finnish teachers used questions in order to support student thinking. All Thai teachers mainly used an experiment utilizing authentic materials in the lab in supporting the students' procedural knowledge. Drawings and pictures were used in teaching the concepts in the electric circuit topic. There were some discipline problems, especially in Thai classrooms, and, therefore, Thai teachers emphasised the behavioural systems family of teaching models.

The main outcomes reflected the fact that the Finnish teachers viewed PCK in terms of student thinking, student misconceptions, and the use of the textbook in representing the concepts when teaching the electric circuit. Referring to GPK, the Finnish teachers were rather flexible in their teaching in terms of the fact that there were no specific techniques to use in handling students; this depended on the situation at the moment. There were no strict rules for student discipline in the classroom. For Thai teachers, their views on PCK emphasised students' procedural knowledge. Students were taught via an experiment with authentic materials in the lab. The textbook was not used as the main representation of the concepts taught. Rules were set regarding classroom tidiness. Although all teachers from the two countries emphasised different aspects of PCK and GPK based on several influencing factors in the countries, this analysis showed that PCK and GPK are still fundamental forms of knowledge for the teaching profession.

The Finnish teachers mentioned that there were no specifics techniques but that the techniques used depended on the situation in the classroom. This may reflect the perspective of flexibility in the Finnish classroom. The adopted flexible accountability system also promotes the use of alternative strategies for raising student achievement in classrooms (Aho, Pitkänen, \& Sahlberg, 2006, pp.9), and it has had a major positive impact on teaching and hence on student learning (Sahlberg, 2009, pp.26). Moreover, a plausible reason to support the idea of flexibility is well-trained teachers in primary school. It is well-known that the instruction in Finnish teacher education programs is arranged in order to reflect pedagogical principles that newly prepared teachers are expected to practice in their own classrooms, from basic to advanced practices. As a consequence of strengthened professionalism in schools, Finnish teachers have considerable classroom independence in terms of selecting the most appropriate pedagogical methods. They can diagnose problems, apply evidence-based conclusions, and use alternative solutions in their classrooms and schools (Sahlberg, 2007). In summary, all of these may call for flexibility in the Finnish classroom.

Secondly, referring to student discipline problems, the analysis found that there were fewer problems in the Finnish classroom, while there were some in the Thai classroom. Based on the idea of class size, at the primary level, the average class size is fewer than 20 students per classroom in Finland (OECD, 2012). In contrast, Wößmann's research (2003) finds that in Thailand, average class sizes are as high as 50 students per class. Consequently, the number of students in the classroom certainly affects to what degree the teacher can control the class and how much time the teacher is able to focus on individual students and their specific needs rather than on the group as a whole. Consequently, classroom size has an influence on student discipline problems in the classroom. Furthermore, OECD performed a survey of discipline in the classroom by interviewing students and found that 62 percent of students reported that the teacher "never or hardly ever" or "in some lessons" had to wait a long time for students to quieten down (OECD, 2011). "In a typical classroom, students are likely to be walking around, rotating through workshops or gathering information, asking questions of their teacher, and working with other students in small groups" (Darling-Hammond, 2010). For this reason, the Finnish teachers may not recognise students' talking and walking in the classroom as being a major discipline problem during their instruction. 
Thirdly, the analysis of teaching models (methods) revealed that both the Finnish and Thai teachers emphasised similarly laboratory methods and experiments for teaching the electric circuit. Hofstein and Lunetta (2003) have been performing research on laboratory use in science education for two decades. They still suggest that the science laboratory is central in our attempt to vary the learning environment in which students develop their understanding of scientific concepts, science inquiry skills, and perceptions of science. Students can work cooperatively in small groups to investigate scientific phenomena. This emphasises the role of the social family of models. In addition, it can also reflect the personal family of models (teaching method) in terms of enhancing personal scientific skills. Another issue is that the Finnish teachers greatly emphasised conceptual instruction and textbook use. This outcome relates to the Finnish science textbook analysis, which found that Finnish textbooks emphasized conceptual knowledge (Sothayapetch, Lavonen, \& Juuti, 2013). Thus, it is no wonder that Finnish teachers took conceptual instruction and the use of the textbook into account during their teaching.

Regarding teaching models (methods), the expressions of the participants showed the same results in terms of classroom communication. Two kinds of interaction, teacher-student and student-student, occur when applying the experimental/lab method in the classroom. For example, the participants began the electric circuit lesson by asking students some stimulating questions and then waiting for the students to answer. After that, the participants provided students with time to work in small group in order to share ideas, discuss, and learn together under the teachers' supervision. Lastly, the participants and students discussed the experimental results, asked questions, and solved some problems that arose during the small group work as a whole class and then concluded with the important concepts for that day. According to the characteristics of teacher-student interaction, this interaction consists of the teacher asking questions with known answers, the students attempting to give the correct answer, and the teacher evaluating the responses in terms of their consistency with the known answer. This is done in order to better understand the teacher's suggestions or requests, the students' replies, and the teacher's evaluations. This method of communication conformed to IRE (Initiation-Reply-Evaluation) concept, created by Mehan (1979). Therefore, all participants realised the importance of teaching model (method) and classroom communication in terms of supporting student learning in science selecting the proper method with which to instruct their students.

Lastly, an important issue is the credibility of this paper. It has an argument concerning the reliability and validity of small samples. Samples for qualitative studies are generally much smaller than those used in quantitative studies (Ritchie, Lewis, \& Elam, 2003). Patton (2002, pp.244) claims, "there are no rules for sample size in qualitative inquiry. Sample size depends on what you want to know, the purpose of the inquiry, what's at stake, what will be useful, what will have credibility, and what can be done with available time and resources." Consequently, the interview-based study involving six participants has become common in social science study. The purposeful random sampling used in this study increased credibility and decreased foster representativeness. Furthermore, one advantage of qualitative interviewing is that it can provide an understanding of things that cannot be directly observed, such as the feelings, thoughts, opinions, attitudes, or behaviours of interviewees. Crouch and McKenzie (2006) researched the use of small samples in interview-based qualitative studies. They argue that a small number of cases (less than 20) will facilitate the researcher's close association with the respondents and enhance the validity of fine-grained, in-depth inquiry in naturalistic settings.

\section{Conclusion}

As mentioned above, the teacher should know how to facilitate students' learning specific topic easily, how to build a congenial relationship with students, and how to teach students well (and in what way this should be done). The sum of these minor details can gradually be shaped into the PCK and GPK of teachers. The highest quality of teaching will appear when the students study with happiness and curiosity. On the other hand, the teacher improves his/her teaching little by little by learning from the students in the everyday classroom context. As Morine-Deshimer and Kent (1999) suggested, students learn more when teachers use time efficiently, implement group and instructional strategies with high levels of involvement, communicate rules and expectations clearly, and prevent problems by introducing a management system at the beginning of the school year.

As a conclusion of the present study, it will be a challenging for both Finland and Thailand to apply the outcomes of this comparison. The comparison tells differences between Finland and Thailand and, moreover, what is possible in science education. For example, the Thai science teachers may learn from Finnish teachers practices how to avoid the discipline problems. However, the first priority for Thai education is the classroom size reduction. Furthermore, the Finnish teachers may learn from the Thai teachers how to organize lab activities in relatively big size classrooms and how 
to balance learning of conceptual and procedural knowledge for students. We are planning to employ classroom observations and the stimulated recall technique along with the interview in order to learn more about the science education practices in these two different countries.

\section{Acknowledgements}

The research presented in this paper was supported by the Thailand Commission on Higher Education.

\section{References}

Aho, E., Pitkänen, K., \& Sahlberg, P. (2006).Policy development and reform principles of basic and secondary education in Finland since 1968. Washington, DC: World Bank.

Anderson, T., \& Garrison, D.R. (1998). Learning in a networked world: New roles and responsibilities. In C. Gibson (Eds), Distance learners in higher education. (p. 97-112). Madison, WI.: Atwood Publishing.

Bransford, J. D., Brown, A. L., \& Cocking, R. R. (2000). How people learn: Brain, mind experience, and school. Washington DC: National Academy Press.

Carlsen, W. (1999). Domains of teacher knowledge. In J. Gess-Newsome \& N. G. Lederman (Eds.), Examining pedagogical content knowledge: The construct and its implications for science education (pp. 133-144). Dordrecht: Kluwer Academic Publishers.

Chick, H. L., Baker, M., Pham, T., \& Cheng, H. (2006). Aspects of teachers' pedagogical content knowledge for decimals. In J. Novotná, H. Moraová, M. Krátká, \& N. Stehlíková (Eds.), Proceedings of the 30 th annual conference of the International Group for the Psychology of Mathematics Education, 2, 297-304. Prague: PME.

Crouch, M., \& McKenzie, H. (2006). The logic of small samples in interview-based qualitative research. Social Science Information, 45(4). 483-499.

Darling-Hammond, L. (2010, October 1). What we can learn from Finland's successful school reform. NEA Today Magazine, Retrieved from http:/ / webcache.googleusercontent.com/search?

Duschl, R., Schweingruber, H., \& Shouse, A. (Eds.). (2007). Taking science to school: Learning and teaching science in grades K-8. Washington, DC: National Academies Press.

Elleuch, N., Bellamine-Bensaoud. N., and Ben Ahmed. M. (2006). Designing educational systems for use: Case study of Tunisian Primary Schools. Information and Communication Technologies: From theory to applications (ss. 66-71). Jurong East: International Conference on Telecom Technology and Applications.

Elo, S. \& Kyngäs, H. (2008). The qualitative content analysis process. Journal of Advanced Nursing, 62(1), 107-115.

Froyen, L. A., \& Iverson, A. M. (1999). Schoolwide and classroom management: The reflective educator-leader (3rd ed.). Upper Saddle River, NJ: Prentice-Hall.

Gess-Newsome, J. (1999a). Pedagogical content knowledge: An introduction and orientation. In J. Gess-Newsome \& N. G. Lederman (Eds.), Examining pedagogical content knowledge: The construct and its implications for science education. Dordrecht: Kluwer Academic Publishers. 3-17.

Gess-Newsome, J. \& Lederman, N. G. (1999b). Examining pedagogical content knowledge. (Eds.) Dordrecht: Kluwer Academic Publishers.

Grossman, P. (1990). The making of a teacher. Teacher knowledge and teacher education. Teachers College Press, Columbia University, New York.

Grossman, P. L., \& Richert, A. E. (1988). Unacknowledged knowledge growth: A re-examination of the effects of teacher education. Teaching and Teacher Education, 4(1), 53-62.

Hashweh, M. (2005). Teacher pedagogical constructions: a reconfiguration of pedagogical content knowledge. Teachers and Teaching: theory and practice, 11(3), 273-292.

Hofstein, A. \& Lunetta. N. V. (2003). The laboratory in science education: Foundations for the twenty-first century. Science Education, 88, 28-53.

Hurt, H. T., Scott, M. D., \& McCroskey, J. C. (1978). Communication in the classroom. Reading, MA: AddisonWesley.

Johnson, M. B. (1999). Communication in the classroom. Educational Resources Information Center,1-15. Retrieved from http: / / www.eric.ed.gov/PDFS/ED436802.pdf

Joyce, B. R., Calhoun, E. \& Hopkins, D. (2002). Models of learning: Tools for teaching (2nd ed.). Buckingham, UK: Open University Press.

Joyce, B. \& Weil, M. (1996). Models of Teaching (5th edition). (pp. 312-318). Allyn and Bacon.

Kansanen, P. (2002). Didactics and its Relation to Educational Psychology: Problems in Translating a Key Concept across Research Communities. International Review of Education, 48(6), 427-441.

König, J., Blömek, S., Paine, L., Schmidt, H. L., \& Hsieh, Feng-Jui. (2011). General pedagogical knowledge of future middle school teachers: On the complex ecology of teacher education in the United States, Germany, and Taiwan. Journal of Teacher Education, 62(2), $188-201$.

Morine-Deshimer, G. \& Kent, T. (1999). The complex nature and sources of teachers' pedagogical knowledge. In J. GessNewsome \& N.G. Lederman (Eds.), Examining pedagogical content knowledge. Dordrecht: Kluwer Academic Publishers.

Mehan, H. (1979). Learning lessons: social organization in the classroom. Cambridge, MA: Harvard University.

Musikul, K., (2007). Professional development for primary science teaching in Thailand: knowledge, orientations, and practices of professional developers and professional development participants. Dissertation. Columbia: University of Missouri.

Nilsson, P. (2008). Learning to teach and teaching to learn: Primary student teachers' complex journey from learners to teachers. Diss. (sammanfattning) Linköping : Linköpings universitet No 19

Nilsson, P., \& Loughran, J. (2012). Exploring the development of pre-service science elementary teachers' pedagogical content knowledge. Journal of Science Teacher Education , 23(7), 699-721.

OECD (2011). PISA in Focus. Retrieved from http://www.oecd.org/pisa/pisaproducts/pisa2009/47034256.pdf

OECD (2012), "How many students are in each classroom?", in Education at a Glance 2012: Highlights,OECD Publishing. Retrieved from http:/ / dx.doi.org/10.1787/eag_highlights-2012-25-en

Patton, M. Q. (2002). Qualitative research \& evaluation methods ( $3^{\text {rd }}$ edition). Thousand Oaks: Sage Publications.

Ritchie, J., Lewis, J., \& Elam, G. (2003). Designing and selecting samples. In Jane Ritchie \& Jane Lewis (Eds.), Qualitative research practice. A guide for social science students and researchers (pp.77-108) Thousand Oaks, CA: Sage. 
Sahlberg, P. (2007). Education policies for raising student learning: The Finnish approach. Journal of Education Policy, 22(2), 147171.

Sahlberg, P. (2009). A short history of educational reform in Finland. Retrieved on April 18th, 2013 from http:/ / 192.192.169.112/ filedownload /\%E8\%8A\%AC\%E8\%98\%AD\%E6\%95\%99\%E8\%82\%B2/A\%20short\%20history\%20of $\% 20$ educational $\% 20$ reform $\% 20$ in $\% 20$ Finland $\% 20$ FINAL.pdf

Shulman, L. S. (1987). Knowledge and teaching: Foundations of the new reform. Harvard Educational Research, 57, 1-22.

Sothayapecth, P., Lavonen. J., \& Juuti, K. (2013). An analysis of science textbooks for grade 6: The electric circuit lesson. Eurasia Journal of Mathematics, Science \& Technology Education, 2013, 9(1), 59-72.

Tobin, K., Briscoe, C., \& Holman, J. R. (1990). Overcoming constraints to effective elementary science teaching. Science Education, 74, 409-420.

van Driel, J. H., Verloop, N., \& de Vos, W. (1998). Developing science teachers' pedagogical content knowledge. Journal of research in Science Teaching, 35(6), 673-695.

Williams, P. (2003). A passion for learning begins with a spark: Message from the president. Funding Innovation, 45(2). Retrieved from http:/ / www.ascd.org/publications/newsletters/education-update/mar03/vol45/num02/A-Passion-for-LearningBegins-with-a-Spark.aspx

Wößmann, L. (March, 2003). Educational production in East Asia: The impact of family background and schooling policies on student performance (Working Paper Series Vol. 2003-17). Retrieved from http: / file.icsead.or.jp/user03/928_214.pdf

Zembal-Saul, C., Krajcik, J., \& Blumenfeld, P. (2002). Elementary student teachers' science content representation. Journal of Research in Science Teaching, 39, 443-463. 


\section{Appendix A}

\section{Teacher Interview Protocol}

I appreciate you letting me observe your class. I have some questions I'd like to ask you related to the classroom lesson and some general questions. Would you mind if I taped the interview? It will help me stay focused on our conversation, and it will ensure I have an accurate record of what we discussed.

\section{A. Personal Information}

1. How long have you been teaching in this school?

2. What is your highest degree achieved? What was your major?

3. In what grade do you teach now?

4. Do you have another position besides your teaching role?

5. Have you ever received any awards for teaching?

\section{B. Pedagogical Content Knowledge}

6. Please describe how do you start teaching the electric circuit? Do you stimulate learning through activity or through listening to a lecture?

7. You always follow the textbook to teach the students? Do you use other methods?

8. How do you support student thinking through teaching about the electric circuit?

9. How do you teach them to learn about the electric circuit connection? In what way?

10. In your opinion, what are the main aims for students when learning about electricity?

11. What is your classroom technique to easily teach the electric circuit to the students?

12. From your point of view, what is the main reason for students to learn the content or concepts regarding the electric circuit?

13. How do you teach the concepts? How do you prevent student misconceptions?

14. How do you know that students understand the idea or concepts you teach? In what way?

15. What other resources will you recommend to the students in order to learn about electricity? Newspapers, museums, the Internet?

\section{General Pedagogical Knowledge}

16. In your opinion, is the science curriculum important for your career? How?

17. What do you need the students to learn about science? Is it the right concept, good characteristics, scientific skills, or all of these together?

18. What is the most important thing in your teaching?

19. When you teach the students about the electric circuit, how do you organize the students? Do they work in small groups, in pairs, or individually?

20. What about learning materials besides textbooks? Do you use anything else in your teaching?

21. How do you manage student discipline problems?

22. What is the relationship between you and students? And among the students? 


\section{Appendix B}

Examples of the original expressions and the bold texts showing the deductive analysis units based on the PCK categories and sub-categories

\begin{tabular}{|c|c|c|}
\hline PCK category: Knowledge of & \multicolumn{2}{|c|}{ Examples of original expressions } \\
\hline \multicolumn{3}{|l|}{ Pedagogy } \\
\hline \multirow[t]{2}{*}{ aims for learning } & Fin & $\begin{array}{l}\text { Of course, they learn to understand how the system } \\
\text { works. The system works to helps them to use } \\
\text { electrical equipments in a safe way. (FT3) }\end{array}$ \\
\hline & Thai & $\begin{array}{l}\text { After they learn, they will understand the reason } \\
\text { why they have to learn about the electric circuit or } \\
\text { electricity: because it is close to our lives to use it, } \\
\text { and we must use it in a safe way. (TT2) }\end{array}$ \\
\hline \multirow[t]{2}{*}{ student thinking } & Fin & $\begin{array}{l}\text { I think mainly, asking questions...why? I } \\
\text { encourage them by asking questions and asking } \\
\text { them to tell me what happens? (FT3) }\end{array}$ \\
\hline & Thai & $\begin{array}{l}\text { Firstly, I always stimulate them by asking } \\
\text { questions. Why is it like that? What happens next? } \\
\text { What happens if we do like this? (TT1) }\end{array}$ \\
\hline \multirow[t]{2}{*}{ student's misconceptions } & Fin & $\begin{array}{l}\text { You know, after the experiment, we might look at } \\
\text { the textbook and give them the concepts. (FT3) }\end{array}$ \\
\hline & Thai & $\begin{array}{l}\text { Students need to conclude the daily concept } \\
\text { together in the classroom after the experiment. We } \\
\text { discuss and check their conclusions group by } \\
\text { group. (TT3) }\end{array}$ \\
\hline \multirow[t]{2}{*}{ procedural knowledge } & Fin & $\begin{array}{l}\text { Yes.... we have learned about the circuit diagram } \\
\text { drawing and then...errrr....there are all kinds of } \\
\text { markings... (FT1) }\end{array}$ \\
\hline & Thai & $\begin{array}{l}\text { I let them work in a group and experiment with the } \\
\text { authentic materials. (TT2) }\end{array}$ \\
\hline \multirow[t]{2}{*}{ resources } & Fin & $\begin{array}{l}\text { We use quite a lot of Internet resources, but I have } \\
\text { always told them that when they use the Internet, } \\
\text { they should be very careful because there are might } \\
\text { be some incorrect information. }\end{array}$ \\
\hline & Thai & $\begin{array}{l}\text { I extend their knowledge by telling them to search } \\
\text { Internet, such by using as Google, YouTube...for } \\
\text { more information that they are interested in. (TT1) }\end{array}$ \\
\hline \multirow[t]{2}{*}{ classroom technique } & Fin & $\begin{array}{l}\text { It always depends on the situation, but in a way, } \\
\text { I'm a traditional teacher, and in the sixth grade, I } \\
\text { also think it's important that they learn to like read } \\
\text { in a book, and we sometimes we go through the } \\
\text { text together and talk about it. (FT2) }\end{array}$ \\
\hline & Thai & $\begin{array}{l}\text { Firstly, I need students to learn science with } \\
\text { happiness and joyfulness, so I try to help students } \\
\text { to be enthusiastic, exciting, and interested and like } \\
\text { doing things through the hands-on experiment. } \\
\text { (TT2) }\end{array}$ \\
\hline
\end{tabular}

\section{Content}




\begin{tabular}{|c|c|c|}
\hline \multirow[t]{2}{*}{$\begin{array}{lll}\text { purpose of } \\
\text { knowledge }\end{array}$} & Fin & $\begin{array}{l}\text { I think, some kinds of skills are used to learn to } \\
\text { solve problem so that when have this kind of } \\
\text { problem in their everyday lives, they will do the } \\
\text { safe thing. (FT1) }\end{array}$ \\
\hline & Thai & $\begin{array}{l}\text { They should learn because this lesson relates to } \\
\text { their lives. (TT2) }\end{array}$ \\
\hline \multirow[t]{2}{*}{$\begin{array}{l}\text { evaluation of student } \\
\text { learning of conceptual } \\
\text { knowledge }\end{array}$} & Fin & $\begin{array}{l}\text { I give them the test about the last lesson, the } \\
\text { concept, and also the things they have been doing } \\
\text { for homework. Sometimes, I check their homework } \\
\text { to see if they have the correct answer. Then, I } \\
\text { assume that they have understood it. (FT3) }\end{array}$ \\
\hline & Thai & $\begin{array}{l}\text { If I would like them to have the right concept, I } \\
\text { always let them connect the circuit by themselves } \\
\text { and see it all together after that. They can see if it } \\
\text { works or not and draw the diagram step by step. } \\
\text { (TT3) }\end{array}$ \\
\hline \multirow[t]{2}{*}{ representation of concepts } & Fin & $\begin{array}{l}\text { I kind of make a conclusion about what they have } \\
\text { been doing, and then, after that, we might look at } \\
\text { the textbook and give names to the concepts. (FT3) }\end{array}$ \\
\hline & Thai & $\begin{array}{l}\text { They have to think together in a group about how } \\
\text { to draw the open circuit diagram. After that, they } \\
\text { have to draw it on the blackboard. When, we check } \\
\text { any point that is missing or incorrect about the } \\
\text { concept together. (TT1) }\end{array}$ \\
\hline
\end{tabular}




\section{Appendix C}

Examples of the original expressions and bold texts showing the deductive analysis units based on the GPK categories and sub-categories

\section{GPK category}

Main Sub-categories $\quad$ Examples of original expressions

1.Classroom
management

Curriculum

Teaching preparation

Learning materials

Students arrangement

1.2Conduct management

Resolve discipline Fin problem
Fin You have to...I think it controls our job that we have to use it. I don't know how, do you say...kind of, well...it's kind of law. It has a static nature, being kind of...it's really... you have to follow it. You can't skip it. (FT2)

Thai It is important. It's kind of a framework or guideline for teaching in terms of what content should be taught, how difficult or deep of content should be taught, and how to teach. (TT3)

Fin I check the student book and the teacher materials. Usually, it has very good points...kind of, how to teach and what the main concept of this lesson is, so I rely very much on the teacher handbook. (TF2)

Thai I study all contents for the semester, including how to organize the lesson and learning materials, and then write the week's lesson plan and think about how to teach and in what way. (TT1)

Fin All kinds of computer materials exists. If there is something that I want to use, but it is not there, then I will make it somehow, and then, of course, I have to check if the...school...err... equipment for this particular...errr...I have checked whether it's working and whether there are enough batteries, wires, and so on. (TF1)

Thai Touchable, experimental, and authentic things...I like to use the authentic things for students doing an experiment. (TT1)

Fin I form students into groups of around 3-4 people in one group. The maximum is four.

Thai Students are grouped about 5-6 people to a group in the LAB. (TT2)

No...no...actually, I have taught many classes during my eight years. I have never met a class that had discipline problems after teaching them, so I think it relates to 
the interaction...between teacher and students, and the students want to act so that they please the teacher as they like the teacher and they respect the teacher, and then, if there is some discipline problem, then they usually are in the class.... (TF1)

Thai I set the rules in the classroom and in the lab and define their responsibilities in terms of taking care and keeping things orderly in the lab. (TT1)

1.3Covenant management

Interpersonal relationships students

Relationship between Fin teacher and students

among
Fin Well, I carefully think about who will work in pairs and who will be in the same group so that they would...errr...they would work at... they can, and also, sometimes, it's better if there is someone who knows a bit more and someone who doesn't know the subject that well so that someone can or that one who doesn't know can learn from the others. (TF1)

Thai I think work in a group is important to support students' relationships. For example, an excellent student can transfer knowledge or experience to other students in a group by discussion and cooperation. (TT2)

I aim to be among the students as much as I can. I aim to walk around, help them, and encourage them as I have to ask, and yes, I also teach, but my moments of direct teaching are quite short. Mainly, I see my role to be that I help them to study. I help them to set their own goals, and I help them to reach their own goals. (TF3)

Thai Actually, students do not dare to come and talk to me, but I try to use conversation, not beating. I sometimes express to students that I care about them and worry about them all the time. (TT3)

2.Instructional The social family of Fin models

I have 26 pupils, so mostly, I form them into groups of $3-4$. I think 4 is quite the maximum. They all can do, they all can try, and everybody can say their opinions. When the groups have an experiment...every time, the real material and working in a group are used. (TF3)

Thai I always use the lab to teach students when they have to do some experiments in a group. (TT1)

The information Fin Well...I like all kinds of problem. We have the problem. How would you solve it? How would you make that thing light up? For example, if we talk about the 
electricity or things like that... what would you need, how does it work, why does it work... and so on. They should find out... (TF1)

Thai First, I stimulate them to think: what happens? Why is it like this? What is the reason? Then, I let them try to find out or inquire by themselves. (TT2)

The personal family of Fin models

The behavioural systems family of models

3.Classroom communication
Teacher-student

Student-student

No interaction
I need some open-mindedness from them and some kind of curiosity. I need the pupils to have ability to ask. They ask questions if they wonder. If they ask hard question to me, then I think they are interested. (FT3)

Thai I think that qualification is quite important in terms of how to learn, how to think, and how to use skills to solve problems and make decisions in every step. (TT1)

Fin No, I'm the book person, you know, so they are in their own places mostly, or we will go to the museum...the museum of the technology. Then, they are in small groups. (TF2)

Thai I have two rules in the classroom: the teacher's rule is about the agreement regarding time for teaching, experimenting, working in a group, and discussing; the students' rule is about the positive and negative reinforcements, such as group score, rewards, and giving stars. (TT2)

Fin I ask them about the prior knowledge regarding the lesson via questions in order to know their background. Then, we discuss on the topic of lesson together, such as electrical phenomena. I let them to work in groups, and I walk around to help them or ask them about the experiment. Lastly, we discuss the results and draw conclusions about the lesson concepts. (TF3)

Thai Firstly, I try to make them think about what is happening, ask them questions, and let them have a discussion in groups. After that, they will perform the experiment in groups with their friends. They have to present the results of the experiment group by group. Finally, we discuss the results together and conclude with the important concepts of the lesson. (TT3)

Fin You know, after the experiment, we might look at the textbook and give them the 
concepts. Then, they might do some exercises from the book. (FT3)

Thai Students will have their own lab book. I don't give them much homework. The lab book is sent at the end of lesson to conclude what the concept for that day is. What concept does this lesson give you? (TT3) 